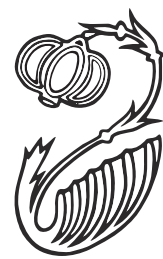

\title{
Law, Politics, and the Question of Relevance in the Case On the Crown
}

\begin{abstract}
This paper seeks to give a more precise grounding to the question of relevance in Athenian forensic argument with a specific focus on the speeches delivered by Aeschines and Demosthenes in the case On the Crown. I argue that in Athenian litigation relevance can be determined quite precisely by the specific terms of the accusation, and that the litigants are well aware of this standard and take care to make their arguments relevant or to justify them if they may appear to be "outside the issue." Because all the issues specified in the accusation are legally relevant, the distinction commonly drawn between legal and political arguments has no place in a discussion of relevance. The effect of this rule of relevance, I argue, is not to promote fairness but to increase the advantage enjoyed by the plaintiff. I conclude with a few observations on the Athenian view of law which, I suggest, was considerably broader than ours.
\end{abstract}

Just as in chariot races, you must keep to the actual track of the subject at issue.

Aeschines 1.176

In the last several decades much scholarly attention has been devoted to reassessing the fundamental nature of Athenian law. One of the issues central to this discussion is relevance. Against the traditional view that Athenian litigants routinely violated modern standards of relevance, ${ }^{1}$ several scholars have recently concluded that most of the arguments in the forensic speeches should be considered relevant by Athenian standards, though not by modern standards

I am grateful to Steve Johnstone for his long-time encouragement of this project, which began as a CAMWS talk in 2005. His comments and those of the two referees on earlier drafts have greatly improved the paper. Edward Harris also made helpful comments on a later draft.

1. E.g., Rhodes 1981: 719: "It is... abundantly clear... that the Athenians did not observe standards of relevance which would satisfy the modern critic..." A similar view continues to be evident in MacDowell 2009: 153-55. For Rhodes' more recent view, see below.

Classical Antiquity. Vol. 31, Issue 2, pp. 293-314. ISSN 0278-6656(p); 1067-8344 (e).

Copyright (C) 2012 by The Regents of the University of California. All rights reserved. Please direct all requests for permission to photocopy or reproduce article content through the University of California Press's Rights and Permissions website at http:/www.ucpressjournals.com/reprintInfo.asp. DOI:10.1525/CA.2012.31.2.293. 
of relevance; scholars remain divided, however, on just what these Athenian standards of relevance were and how they operated in practice.

One line of approach, evident for example in Yunis' treatment of graphe paranomōn cases, is to discover those kinds of arguments that are always or frequently found in Athenian litigation or in certain types of litigation, and then conclude that such arguments were functionally necessary for conviction in such cases and were thus relevant in the eyes of the jury. ${ }^{2}$ Lanni applies a similar line of argument more broadly to all Athenian litigation except homicide and maritime cases, which had their own courts and their own specially strict rules of relevance. For all other cases, she argues, although no rule of relevance applied, several types of "nonlegal" (or "extralegal") arguments-concerning the background of the case, the characters of the litigants, or the reasons for having (or not having) pity-occur so regularly that these must have been "vital components in making a case" and thus can be considered relevant. These arguments do not work against the legal issues in a case but rather "contextualize" the dispute, thereby assisting the court in reaching a verdict. ${ }^{3}$

Rhodes 2004 has recently taken a somewhat different approach. He surveys almost all the surviving forensic speeches and concludes that most of the litigants' arguments are relevant: "on the whole, if we grant that the point includes its wider context, Athenian litigants were much better than we have allowed at keeping to the point" (156, italics mine). In some cases Rhodes specifies fairly clearly what (in his view) this wider context was, but he never indicates exactly how he determines this context or how it might have been determined by litigants or jurors; consequently, many of his assertions that an argument is or is not relevant seem purely subjective. ${ }^{4}$ By this loose standard, virtually any argument might be considered relevant.

In this paper I argue that there was in fact an objective standard of relevance in Athenian litigation so that in each case relevance was defined quite precisely, that litigants were acutely aware of this standard and of the rule that they should stick to the point and regularly tried to justify or otherwise excuse arguments that might at first glance seem to be outside the issue, and that they referred to this standard in criticizing their opponent for speaking "outside the issue."

2. Yunis 1988 first separates "political pleas" from the "numerous irrelevant arguments and considerations" found in graphē paranomōn speeches (361), and then argues that "the political pleas were viewed as not only relevant but in fact necessary in order for a prosecutor to secure a conviction" (369).

3. Lanni 2005; the argument is more fully developed in Lanni 2006.

4. E.g. "it might be argued that... is relevant" (139), "may be regarded as straying too far from the accusation" (140), "acceptably relevant" (140), "contain nothing irrelevant, if we allow that the whole of the larger story is relevant" (146), "a generous interpretation of relevance can accommodate the other instances" (151). To be sure, relevance is not as precise or straightforward in modern law as is sometimes thought (see Lanni 2006: 8-9), but it is not so vague as these expressions suggest. One may often agree with Rhodes' judgments, but this does not make them any less subjective. 
We may begin with the report in Ath. Pol. 67.1 that in private suits litigants

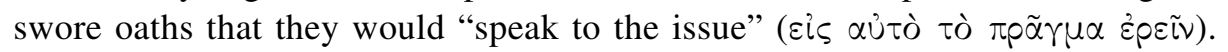
Lanni (2006: 100-101) argues that the report is wrong because litigants before the popular courts do not mention any such oaths but speak only of it being appropriate to stick to the issue; Rhodes (1981 ad loc., 2004: 137), however, not only accepts the rule but expresses doubt that it was confined to private suits. Rhodes is probably correct: although in most cases litigants do not mention oaths, the large number of references to sticking to the issue in public as well as private speeches of all sorts suggest that there was such a rule, though whether it was a formally enacted statute or only an accepted customary rule is unclear. ${ }^{5}$ In neither case would there have been any formal means of enforcing the rule, but extreme or unwarranted departures from the issue would presumably have an influence on the jurors' final verdict, and the well documented "uproar" (thorybos) that was a common feature of Athenian litigation (Bers 1985) could help prevent litigants from straying too far from the issues.

If we accept that the rule existed, the question then becomes, how did litigants (and jurors) determine what the issue was that they were supposed to stick to? Lanni points in the right direction when she defines "extra-legal" as "information and argumentation in the court speeches that do not bear on the application of the formal charge to the facts" (2006: 7), but unfortunately she does not explore further the key idea here, namely the formal charge. Thür, however, has recently shown that in Athenian law the formal charge was determined quite precisely by the plaintiff when he initiated the case by filing an enklema ("complaint") in an ordinary private suit ( $\operatorname{dik} \bar{e})$, or a graphe ("indictment") when the procedure was a graphe or other public case. ${ }^{6}$ The graphe , as the name indicates, was probably always written down when it was filed, and the enklemma was written by the early fourth century at the latest. In either case the accuser specified, sometimes at considerable length, the full details of accusation, and this document then determined the issues in the case, so that any argument directed at a point that was included in the charge was relevant. When at the beginning of each year the jurors swore in their jurors' oath, "I will cast my vote concerning the issue which

5. A possible reason for the discrepancy between the language of litigants before the Areopagus, who speak of a nomos requiring them to stick to the issue (e.g. Ant. 6.9), and litigants in the popular courts, who speak of appropriateness vel sim. (see Lanni 2006: 100-101), may be that there was a written statute in the former court but only an accepted custom in the latter. For my purposes, however, if litigants in the popular courts are clearly aware of the rule and take it into account in constructing their arguments, then it is not so important whether the rule was a written statute or an unwritten but widely accepted rule.

6. Thür 2007: esp. 143-49 (English version, Thür 2008: esp. 66-72). In other public procedures the accusation sometimes took the name of the procedure; e.g., it was called an eisangelia in the impeachment procedure (eisangelia). Thür thinks that the defendant's response to the accusation, often called an antigraphe , also helped to determine the issue, but as far as we can tell, this response is commonly just a straightforward denial of the accusation (e.g., Dem. 45.46) and for our purpose can be ignored. 


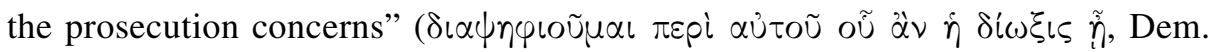
24.151 ), they meant concerning the formal charge as it was determined by the prosecutor. $^{7}$

To see how this worked in practice, we must look at specific examples. Regrettably, few examples of the precise text of the formal charge have survived, but we do have part or all of five accusations from classical Athens that are likely to be genuine. ${ }^{8}$ The best known of these is the indictment of Socrates, preserved by Diogenes Laertius (2.40):

Meletus son of Meletus of Pitthos indicted and swore an oath against Socrates son of Sophroniscus of Alopece. Socrates does wrong (adikei) by not recognizing the gods the city recognizes but introducing other new divinities, and also by corrupting the youth. The proposed penalty is death. ${ }^{9}$

Socrates was indicted in a graphe on the general charge of asebeia ("impiety"), the term designating a legal category of wrongdoing. Asebeia, however, is not mentioned in the indictment that Meletus wrote, which charges Socrates with "wrongdoing" (adikein) and then lists the specific acts which constitute the alleged wrongdoing. ${ }^{10}$ And it is precisely this list of alleged wrongs that controls the arguments in this case. ${ }^{11}$ In other words, the issue in the case was not whether

7. The exact wording of the jurors' oath is not certain, but almost all scholars accept that this clause was part of it (e.g. Mirhady 2007, Harris 2006b: 57). Apollodorus clearly alludes to the clause in Dem. 45.50.

8. Dem. 37.22-29, 45.46, Dionysius of Halicarnassus Dinarchus 3, Plutarch Alcibiades 22, Diogenes Laertius 2.40; one other fictional indictment, Aristophanes Wasps 894-97, is a realistic imitation. All these are noted by Harrison (1971: 91-92). Thür (2008: 68-69) adds Isocrates 15.5 (Antidosis), but this is too loose a paraphrase of the (fictional) charge to shed light on this matter. Thür also cites Dem. 32.37, where the speaker refers to an enklèma in another, related case, but here too it is impossible to know which of the points mentioned by the speaker were explicitly stated in that complaint. For the indictment in the case On the Crown, see discussion below (with n.19).

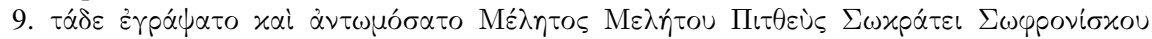

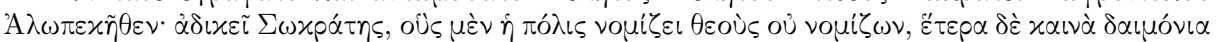

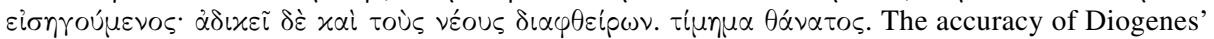
reported text is not absolutely certain, but gains support from the fictitious indictment of the dog Labes in Wasps 894-97 (produced in 422), whose wording is remarkably similar: "Cyon [Dog] from Cydathenaeum indicts Labes from Aexone for wrongdoing (adikein), in that by himself he ate up

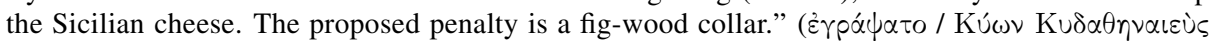

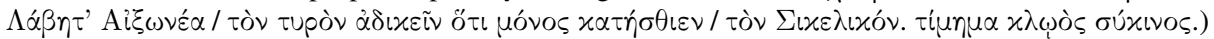

10. The case in the Wasps (see preceding note) would probably have been a graphe klopēs ("indictment for theft")—-see MacDowell 1971: 250-51 (note on 896). As in Socrates' case, theft is not mentioned in the indictment, which similarly refers only to "wrongdoing" (adikein). Adikein is also used in the eisangelia brought against Alcibiades, as preserved in Plutarch (Alc. 22).

11. Complaints in cases brought by the traditional dike procedure are similar except that they are generally worded in personal terms ("X wronged me") instead of as third-person statements ("X indicts Y"), and the general category of the charge is mentioned; see the complaint in Dem.

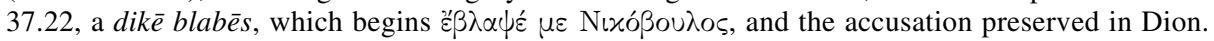
Hal. Din. 3 which, though referred to as a graphē, is almost certainly from a dike blabess. The accusation preserved in Dem. 45.46, a dike pseudomartyriōn, is also a first-person statement, though 
Socrates is guilty of asebeia in general, but whether he committed the specific acts alleged in the indictment. Accordingly, at least in the version of his speech in the Apology, Socrates says nothing about asebeia aside from a brief allusion in his concluding remarks, ${ }^{12}$ but argues entirely against the specific accusations stated in the indictment - that he recognizes other, new gods, not the city's gods, and that he corrupts the youth. These were the issues that provided the legal basis for the case, and even if no Athenian statute explicitly mentioned introducing new divinities or corrupting the youth, these were the issues the two sides had to address and the jury had to decide. Any argument addressed to one of these issues was relevant under Athenian law.

The case On the Crown reveals a similar role for the indictment in determining the relevance of the litigants' arguments. Even though the full wording of the indictment from this case is not preserved, both litigants refer to it at some length and cite parts of it, giving us a clear idea of its significant points. This is one of the few cases in which the speeches of both litigants are preserved-Aeschines' Against Ctesiphon (3) and Demosthenes' On the Crown (18). ${ }^{13}$ Because the case was a graphē paranomōn, or indictment of an illegal decree (and its proposer), in which the accuser charged that a decree proposed or passed in the assembly violated one or more existing Athenian laws, a unique requirement was imposed on the plaintiff: as in other cases, his indictment listed in detail the specific charges against the proposed decree, but it also had to include the text of at least one existing law that the decree allegedly violated. The text of this law (or laws) would then be written down on a wooden tablet next to the text of the decree, and this tablet would be posted, first by the statues of the eponymous heroes, and then in court during the trial. ${ }^{14}$ The prosecutor could also include other objections to the decree in his indictment, and all preserved graphe paranomōn cases include objections to the content of the decree as well as the charge that it violated a specific law.

it is preceded by a third-person statement. This accusation is probably typical of cases of false testimony, where its main function is to indicate what part of the accused's testimony is alleged to be false.

12. Socrates refuses to beg the jurors, since that would not be honorable or just or pious (hosia),

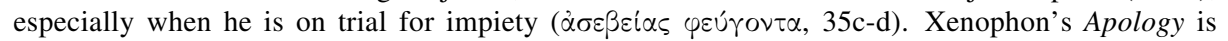
similar in addressing the specifics of the indictment and not mentioning asebeia except to accuse others of it (24).

13. My translations of these speeches are adapted from the translations of Carey (2000) and Yunis (2005). I leave aside the question of whether these speeches were revised after presentation (see Todd 2005: 108-109 with n.38). I myself think substantial revision is unlikely, but even if both speeches were heavily revised, the versions we have must deal with the matter of relevance in the same ways as litigants in court might.

14. See Sundahl 2000: 37-50. The "law" cited in the indictment could of course be, and probably often was, only a single clause or two out of the complete text of a law. The indictment may only have cited those parts of the decree that allegedly violated the law, but when it was written on the tablet, the full text of the decree would be written below the indictment, and the laws it allegedly violated would be written next to the decree; these were the "laws written side-by-side" (paragegrammenoi nomoi). 
Recent analysis of Athenian graphe paranomōn cases, following the lead of H. J. Wolff's fundamental study, generally distinguish between legal argumentsthose that allege the violation of a specific statute - and political arguments - those that question the truthfulness or the expediency of the decree. ${ }^{15}$ Disagreement arises, however, concerning the relative importance of each type of argument and the overall purpose of the graphe paranomōn procedure. On the former question, Wolff argues that legal arguments normally predominate, although the case On the Crown is a clear exception. ${ }^{16}$ Hansen (1974), on the other hand, argues that the graphe paranomōn was both a legal and a political prosecution. Yunis (1988: 369) follows Hansen in concluding that both legal and political arguments were necessary for conviction (see also Lanni 2009: 239). From a strictly procedural perspective it is clear that the requirement that a law be written next to the decree in a graphē paranomōn case makes at least some sort of statutory argument necessary; ${ }^{17}$ if political arguments are also necessary, then we must conclude that the graphē paranomōn was a political as well as a legal process. As we shall see, however, the distinction between law and politics that underlies these arguments is not useful in analyzing the issue of relevance in Athens; for the Athenians, I will argue, the arguments we see as political were in fact just as relevant legally as those we see as legal.

The case On the Crown was tried in 330 BCE. It resulted from Aeschines' prosecution of Ctesiphon, who six years earlier had proposed a decree directing the city to award a crown to Demosthenes for his past services. Aeschines indicted Ctesiphon and his proposed decree on the grounds that the decree violated two specific laws-concerning the proper time and the proper place for awarding crowns - and also that in justifying the award, the decree falsely praised Demosthenes' public career. Ctesiphon was assisted in his defense by Demosthenes, whose technical role was that of supporting speaker (synēgoros),

15. Wolff 1970. Hansen (1974: 28-43) gives a complete list of graphē paranomōn cases known from Athens. See also Yunis 1988, 2001: 8-9. Discussion (e.g., Hansen 1974) often includes the

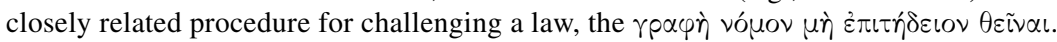

16. In that case, as Wolff sees it (1970: 61), Demosthenes' "more convincing personal stature" (überzeugenderen Persönlichlkeit) prevailed over Aeschines' “indisputable legal position” (unzweifelhafte Rechtslage).

17. This requirement also supports the common comparison of graphē paranomōn cases with the process of judicial review, especially in its US version. Such a comparison generally gives a role to non-statutory arguments in Athenian courts. Lanni 2009 argues that the graphe paranomōn tested statutes (including decrees) against established democratic principles and procedures (not just against existing statutes). Along the same lines, Sundahl 2009 suggests that because the Athenians never enacted broad moral or political principles in the form of laws, they used the graphe paranomōn process to test decrees against these principles. Carawan 2007 argues that judicial review was not the original purpose of the graphē paranomōn procedure, but he infers far too much from Xenophon's report of the trial of the generals after Arginusae $(H G 1.7)$, which says almost nothing about the procedure (1.7.12). 
but since Aeschines' prosecution was clearly aimed at Demosthenes, he was in fact speaking in his own defense. ${ }^{18}$

The full text of the indictment is not preserved, though it was read out during the trial at Demosthenes 18.54-55. ${ }^{19}$ Both speakers, however, cite and discuss parts of it, enabling us to reconstruct the relevant parts of both Ctesiphon's decree and the indictment, which clearly quoted parts (or perhaps all) of the decree. Both Aeschines and Demosthenes cover a wide range of topics in their speeches, including discussion of the two specific laws about awarding crowns and a broad review of Demosthenes' public career. Both also include passages of strong personal attack and harsh invective that all scholars consider irrelevant. The two litigants, however, try to justify these discussions of character as relevant to the issues of the case, and a close examination of their arguments will show that to some extent they succeed.

Aeschines, as plaintiff, speaks first. He begins (9-48) by arguing that Ctesiphon's decree violates two specific laws, one prohibiting the award of a crown to an official who has not yet passed his audit, the other stipulating that crowns approved by a decree of the assembly, as this one was, should be awarded in the assembly "and nowhere else" (Ctesiphon had proposed awarding the crown in the Theater of Dionysus). On both points he has the clerk read out the laws that pertain to these specific matters, which demonstrate (he argues) that the decree is in violation of the established laws.

After his arguments about these two laws, Aeschines next turns to the broader issue of Demosthenes' career (49-50):

The remaining part of my prosecution is the one I am particularly concerned about. This is the reason for which Ctesiphon sees fit to have him crowned. This is what he says in his decree: "And the herald is to announce in the theater to the Greeks that the Athenian demos is crowning him on account of his virtue and integrity"-and then the most important point- "because he consistently speaks and acts in the best interests of the demos." [50] The rest of my case is absolutely straightforward and it will be easy for you to judge when you hear it. Surely I, as prosecutor, must prove to you that the praise devoted to Demosthenes is false, that he neither began his career by speaking for the best nor does he consistently act to the advantage of the demos. And if I prove this, Ctesiphon will certainly be convicted justly with respect to the indictment; for all the laws forbid anyone to write false statements in public decrees. The

18. Ctesiphon probably did little more than come up to the speaker's platform and tell the court that he was handing over his time for pleading to Demosthenes.

19. The text of the indictment preserved in our mss., like all the documents in the mss. of this speech, is now unanimously agreed to be a later forgery. 
defense must prove the opposite of this, and you will be judges of our arguments. $^{20}$

It is clear from this that in his indictment Aeschines cited (at least) that part of Ctesiphon's decree quoted in this passage, and then charged that the decree not only violated two specific laws concerning the time and place for awarding decrees, but also that it violated "all the laws" by falsely claiming that Demosthenes deserved the award. Aeschines clearly implies, moreover, that this last charge is the most important. If he can prove this, he says, Ctesiphon will be justly convicted "with respect to the indictment."

Almost all scholars who have judged the merits of the case On the Crown have concluded that Aeschines had the stronger argument on the first two points, namely that the decree violated two specific laws, but that Demosthenes won the case by concentrating on the third issue, his political career, and persuading the jurors that the praise contained in Ctesiphon's decree was truthful. ${ }^{21}$ On this analysis, the case can be seen as confirming the political nature of Athenian litigation, which scholars have traditionally deplored, though some recent scholars find the political use of the courts more acceptable (e.g. Todd 1993: 158-60). Against this view, Harris has argued forcefully that regardless of the political issue, Demosthenes' legal arguments are the stronger ones, and that On the Crown therefore supports the view that the Athenians respected the rule of law and did their best to judge cases according to the relevant statutes. ${ }^{22}$

This debate among scholars is futile. In a similar case in the United States, if the two sides presented conflicting arguments concerning a point of law, an appellate court (and ultimately the Supreme Court) would rule on the issue; their ruling would settle the question and would ipso facto be correct, though in many such cases legal scholars continue to debate whether the court truly made the right decision. In Athenian law, however, no decision was ever made on points of law by themselves; because the jury voted just once, and because their verdict was based on the entire set of arguments in the case, we can know nothing about their

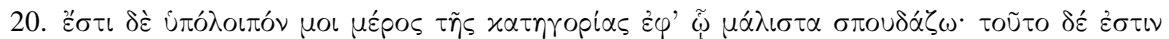

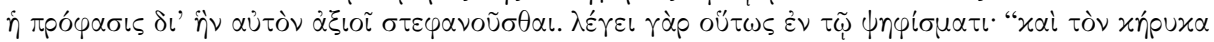

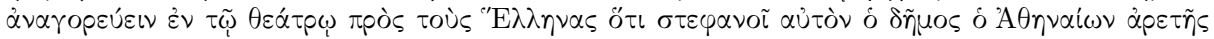

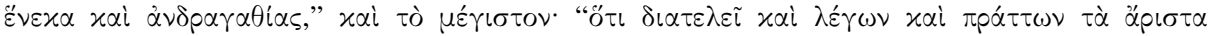

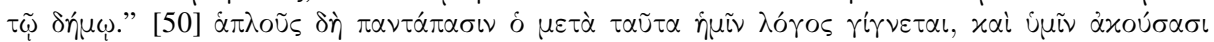

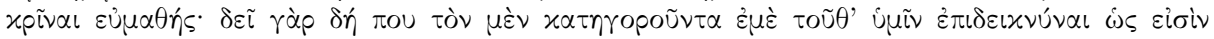

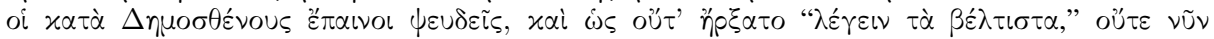

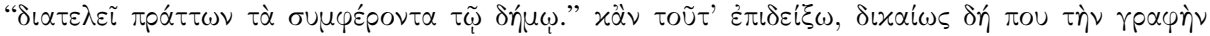

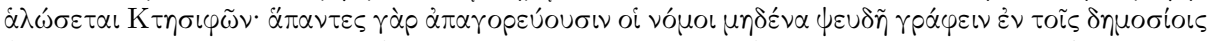

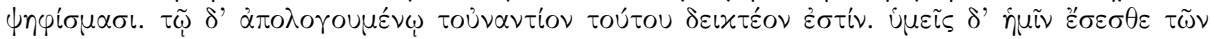
$\lambda o ́ \gamma \omega \nu$ xpıฉai.

21. Gwatkin 1957; Wolff 1970: 61 (referring to Aeschines' "indisputable legal position," see above, n.16); Yunis 1988: 365 (Aeschines' legal plea was "patently incontrovertible”).

22. Harris 1994, 2000: 59-67. MacDowell 2009: 388-89 rejects Harris' argument on the first law cited concerning audits (388n.20); he is less certain on the second law concerning the place of the award, but suspects that Aeschines is correct on this point too. 
judgment on any single issue. All we can say, then, is that each litigant argued for his interpretation of the laws regarding these two points. Most likely, the opinions of the jurors and others were mixed, just as is often the case today. It makes no sense, given the Athenian system, to say that one side is correct on these points.

The more important point to note is that Aeschines himself, far from relying on his arguments concerning the two specific laws, not only emphasizes in the passage above the greater importance of the third issue, Demosthenes' career, but spends far more time in his speech discussing this point. Out of the 260 sections in modern editions, he devotes only 40 (9-48) to discussion of the two laws allegedly violated, whereas his discussion of Demosthenes and his career is the direct subject of 117 sections (51-167), and is indirectly addressed in other sections. True, Demosthenes devotes even less time to the first two issues in his speech (12 sections out of 324), but this only confirms that both speakers consider the third issue the most important.

The other significant point is that Aeschines explicitly construes the issue of Demosthenes' career as a legal issue tied directly to his indictment. As he says, he indicted Ctesiphon's decree on this point because in falsely praising Demosthenes, the decree violates "all the laws." And since this charge was included in Aeschines' indictment, if he proves his case on this issue, Demosthenes "will be convicted justly with respect to the indictment." Just like his arguments concerning the time and place of awarding the crown, then, Aeschines' criticism of Demosthenes' public career speaks directly to one of the points in his indictment (so Rhodes 2004: 153). He expresses no difference between his first two arguments about the laws and this third issue, except that his third charge is the most important issue in the case. There is no hint here of the common modern distinction which brands this last issue "political" as opposed to "legal." Rather, the issue of Demosthenes' career is explicitly said to be relevant in the same legal terms as the other two issues.

Critics have argued that Aeschines' claim, that "all the laws" prohibit false statements in decrees, implies that no single law explicitly prohibited this practice; otherwise Aeschines would have cited the law. Therefore, they conclude, this argument probably has no legal basis. ${ }^{23}$ A similar argument could probably be made about Meletus' charge that Socrates corrupted the youth, and even the prohibition on introducing new gods was probably not a written statute. But Athenian legal terminology generally left broad terms like asebeia undefined, allowing plaintiffs to specify a wide range of behaviors in their accusation, none of which were mentioned explicitly in the statute. It was unnecessary to argue that

23. So Gwatkin 1957: 130, though he admits that Aeschines' assertion "must not have seemed too unreasonable." MacDowell (2009: 385) is more cautious: "probably we should conclude that there was no law explicitly forbidding falsehood in a decree, but everyone accepted that it was wrong." If there was such a law, not only would Aeschines almost certainly have cited it, but it would have been written down following the text of his indictment next to the decree among the "laws side-by-side" (see above, n.14). 
corrupting the youth (or introducing new gods) was an instance of asebeia, and any argument to the contrary would have been seen as an attempt to justify obvious wrongdoing. Unlike today, no one would have thought to argue for acquittal in court on a charge of corrupting the youth or lying in a decree on the ground that no law explicitly prohibited these acts. ${ }^{24}$

Thus, Socrates never suggests that corrupting the youth is not a violation of the law, and as we will see, Demosthenes readily agrees that if Ctesiphon's praise of his career is false, then Aeschines' charge is valid. In other words, the relevance of Demosthenes' career in this case stems not from any specific law prohibiting lying in decrees, but from the inclusion in Aeschines' indictment of the charge that Ctesiphon's praise of Demosthenes' career is false and that it is a violation of all the laws to include false statements in a decree. We may presume that there was general agreement that lying in a decree was wrong, and since both litigants agree that an assessment of Demosthenes' career speaks directly to the indictment and is thus directly relevant to the case, the jury and the rest of the audience must have accepted the point as well.

Demosthenes' response on this matter is cast in remarkably similar terms (53-59):

I wish now to defend myself with respect to the indictment itself (peri tēs graphès autēs) and to describe my accomplishments so that... Aeschines may hear why I rightly deserve to receive those proposed honors and even more than these. Read the indictment. [The indictment is read.] ${ }^{25}$ [56] These are the points in the decree that he has chosen to prosecute. From them I will make it clear to you that my entire defense is just... [57] According to the decree I always acted and spoke in the best interests of the demos and I was always eager to do whatever good was in my power, and for these reasons I was to be commended. Because of this, I think the decision in this case depends on my public deeds, for by examining them we can discover whether what Ctesiphon wrote about me in his decree is true and appropriate or whether it is false. [58] With respect to the fact that Ctesiphon did not include the expression "when he has submitted to an audit," and specified that the crown should be proclaimed in the theater, I believe that these points are part of my public record, whether or not I merit the crown and a ceremony before the citizens. I recognize, however, that the laws that permit Ctesiphon to formulate the decree in this way must be specified. In this way, men of Athens, I know my defense will be just and straightforward, and I shall move on to my career. [59] But no one should suppose that my speech strays from the

24. Lycurgus 1.68 says that some of Leocrates' supporters argue that his leaving the city was not treason because the Athenians fled to Salamis in 480; they do not argue that no law prohibited it. Lycurgus heaps scorn on the comparison with Salamis, but the argument suggests that his indictment may have gone beyond the ordinary understanding of the term treason ( $\pi p o \delta\llcorner\delta o ́ v \alpha l)$.

25. On the document preserved in our mss. here, see above, n.19. 
indictment if I enter into a discussion of Greek affairs. By prosecuting the decree for its claim that in word and deed I advanced your best interests and by indicting this claim as false, Aeschines is the one who has made a discussion of all my public acts relevant and essential to the indictment (oikeious kai anankaious tēi graphēi).

Demosthenes here confirms what we already know from Aeschines' speechthat the indictment accused Ctesiphon's decree of violating two specific laws and of making false statements in justifying the award of a crown to Demosthenes because he always spoke and acted in the best interest of the demos. Both litigants thus agree that these are the three relevant issues in the case, and in this respect neither litigant distinguishes legal issues from non-legal or political issues. Modern analysis sees the third issue as significantly different in kind and would accept only the first two as legally relevant, but both litigants, and presumably also their audience, treat all three as relevant in the same way, because all three are explicitly included in Aeschines' indictment. Thus, if the Athenians considered the first two issues "legally relevant" (though such an expression is not used in Greek), they would necessarily also consider the "political" issue legally relevant, for on each issue Aeschines' accusation expressly stated that the decree violates the law with respect to that issue.

Now, although the division of arguments in graphē paranomōn cases into legal and political has no bearing on the question of relevance in Athenian law, the litigants do at times suggest that the two issues concerning violations of specific statutes represent a special kind of illegality not present in other violations of the law. This is most easily seen later in Aeschines' speech when, in the course of a brief summary of his arguments, he uses the expression to paranomon, "the [matter of] illegality," to identify his first two charges, that Ctesiphon's decree violates two specific statutes (205):

I began by demonstrating that the laws forbid the crowning of men subject to audit.... Secondly I gave you an account of the laws governing proclamations.... After saying this I spoke briefly about his private life, though most of what I said concerned crimes against the state. This then is the way you should expect Demosthenes too to present the defense, first of all with the law dealing with men subject to audit, second with the law dealing with proclamations, third and most important, the argument that he is in no way unworthy of the award. If he asks you to make a concession to him on the order of his argument, with the firm promise that he will refute the charge of illegality (to paranomon) at the end of the defense, don't make any concession and don't fail to recognize that this is a feint to trip the court up; for he will never willingly defend himself against the charge of illegality later on.

Although Aeschines here reiterates that the third charge, concerning Demosthenes' public career, is the most important, he wants to make sure that Demos- 
thenes also addresses his first two arguments about violations of specific laws, which he evidently feels are particularly strong. For convenience, he identifies these as to paranomon. ${ }^{26}$

Demosthenes uses the same expression when he begins to address the first two issues (110):

I leave aside my most important political achievements, because, first, I should next give you an account of the specific issue of illegality (autou tou paranomou) and second, even if I say nothing about the rest of my public acts, each of you is nevertheless aware of them.

Like Aeschines, Demosthenes here uses the expression to paranomon to identify the charge that the decree violated two laws, but as we have seen, he treats this illegality issue as a relatively minor part of the indictment, keeping his discussion of it exceedingly brief. And he never suggests that an assessment of his whole career is in any way non-legal or extra-legal.

In both passages just cited, one might be tempted at first glance to think that the speakers' use of to paranomon implies that the arguments about the two specific laws are the legal issue, as opposed to the assessment of Demosthenes' public career, which is not; but clearly neither speaker is saying this. Both use the expression to paranomon simply to identify the charge that the decree violates two laws, not to identify a legal issue in the modern sense as opposed to a non-legal or political issue. The only reason why two specific issues in this case can be labeled "the illegality issue" is that the case is a graphe paranomōn, and such cases had to include a charge that a decree violated a specific law; in no other kind of case can any point in the accusation be designated to paranomon.

Now, if the three main issues in the case, the alleged violations of two specific laws and the falsity of Ctesiphon's praise, are all relevant according to Athenian law, what about the discussions of character in the two speeches? Even Rhodes, who agrees that Aeschines' and Demosthenes' political careers are relevant, nonetheless concludes that the "sections on the litigants' characters... are irrelevant to the formal charges. ${ }^{27}$ Let us look more closely at how the litigants introduce their discussions of character.

Aeschines first raises the issue when he faults Demosthenes for not mourning after his daughter's death because he was more concerned about Philip's death (78):

26. Aeschines uses to paranomon twice in the following section (206) as he continues to urge the jurors not to let Demosthenes avoid these two issues; he has also used the expression earlier, once to identify the charge in this case (31), and twice in general references to the procedure in graphē paranomōn cases $(192,197)$. Demosthenes uses the expression in 18.110 (see below), and also in 7.25 and $23.19,22$, and 23 to refer to a specific decree that he claims is illegal. To paranomon in the singular occurs in no other orator, though the plural is used more widely of illegal decrees or of graphe paranomōn cases in general.

27. Rhodes 2004: 155; he offers no clear justification for this claim. 
And I'm not blaming him for his misfortune but exposing his character (tropos). For a bad father who hates his children could never be a good public leader (démagōgos); and a man who does not love his nearest and dearest will never feel concern for outsiders like yourselves; nor could a man who is base in his private life be of use in public life; and a man who is worthless at home can never have been a man of honor as ambassador in Macedonia-it was his position (topos), not his disposition (tropos), that he changed.

A man's character, in other words, as indicated by his conduct in his private life, does not change when he enters public life; thus Demosthenes' private life is evidence for the kind of person he is in public. This presumption that a person's character is consistent through different areas of that person's life underlies much of the discussion of character in forensic oratory, and would likely have been accepted with few or no reservations by jurors. ${ }^{28}$ We may feel that a person's character, public or private, does not necessarily determine what he accomplishes in his public career, but Aeschines explicitly connects the two later in his speech when he begins a longer discussion of Demosthenes' character (168-76). Seizing on Ctesiphon's claim that Demosthenes always benefited the demos, he questions whether Demosthenes is truly demotikos, "a friend of the people." He begins sarcastically (168):

Oh yes, but he is dēmotikos! Of course, if you look only at the nice sound of his words, you will be deceived, as in the past; but if you look at the

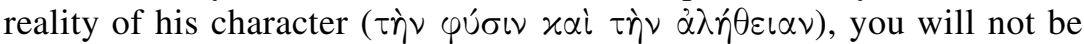
deceived. Hold him to account in that way. For my part, I will reckon up with your help the character that a person should have if he is loyal to the

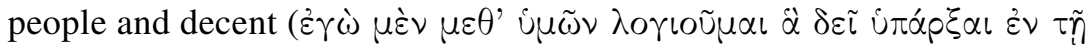

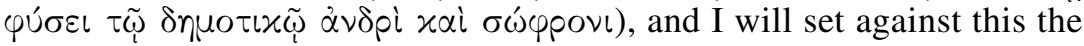
sort of character a person probably has if he is an oligarch and worthless

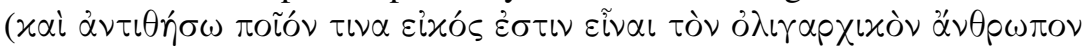
$x \alpha i$ $\alpha \tilde{u} \lambda \circ \nu)$. Then you should compare these two and see which one he belongs to-not in his words but in his life.

For Aeschines, then, Demosthenes' character is relevant because a man's public actions are directly tied to his character; and an assessment of his character is thus relevant to an assessment of his conduct.

Demosthenes does not disagree on the connection of character and action, but he derides Aeschines' method of assessing character, by comparison of a person with some abstract standard, as mere words (122). For him, the discussion of character in this case requires direct examination of a person's life since childhood. Moreover, he does not just defend his own character but attacks

28. Lanni 2006: 60-61 cites other passages from the orators that make a similar point; she also gives references to earlier scholarship. See also Aristotle's discussion of èthos in the Rhetoric (especially Book 2.12-17). 
Aeschines' character, which is less obviously relevant to the issue of his own conduct. Demosthenes is well aware that others may consider such an attack outside the issue, and so he justifies it as a necessary response to Aeschines' attack on his character. This line of argument is first hinted at at the beginning of the speech, when after praying that the gods will inspire the jurors to decide "about this indictment," he continues (9):

If Aeschines had restricted his accusations just to the issues under prosecution, I too would begin my defense with the preliminary decree..$^{29}$ But since he spent much of his speech discussing other matters and mainly told lies about me, I think it necessary and just, Athenians, first to say a few words on these points so that none of you will be guided by irrelevant arguments (tois exōthen logois) or listen with any hostility to my just arguments about the indictment (hyper tēs graphēs).

Litigants, of course, regularly accuse their opponents of lying and of speaking outside the issue, so we should not make too much of these claims here. The more important point for us is that Demosthenes directly contrasts Aeschines' irrelevant arguments ("outside the logos") with his own arguments concerning the indictment. His language here is general, but it is clear that the attack on his character is one of the issues he has in mind, as he indicates in the next section (10), where he briefly notes that the jurors know him and know that he is not that sort of person. ${ }^{30} \mathrm{He}$ continues along these lines when he later takes up the issue of character, claiming that he is forced to speak about it (126):

Despite my reluctance to defame, the slanders he uttered compel me to reveal the facts about him, expose his many lies, and explain the identity and origin of this person who so casually initiated the abuse.

Now, this may seem a pretty flimsy justification, and some in his audience may not have accepted it, especially since Demosthenes' abuse is far harsher than Aeschines' prior criticism. Whatever thread may connect the discussion of character to the indictment, at times Demosthenes seems to stretch it past the breaking point. But we must also recognize two additional factors that help link the attack more directly to the indictment.

29. Since Ctesiphon's decree was indicted before it was voted on, it was technically a "preliminary proposal" (probouleuma), not an actual decree.

30. The more important argument alluded to in 18.9 as "outside the issue" concerns the early part of Demosthenes' public career, which Aeschines had quite reasonably located at the time of the Peace of Philocrates in 346 (3.58-76). Demosthenes claims that his career did not begin until after this. In point of fact, Demosthenes wrote his first speech for a public case in 355 (Dem. 22), he was speaking out on public issues in the Assembly as early as 354/3 (Dem. 14), and he was a member (together with Aeschines) of the embassy that negotiated the Peace of Philocrates. But the Peace was widely considered a failure, so Demosthenes understandably wishes to dissociate himself from it and the events surrounding it. Thus, his account of the Peace and its aftermath in 17-52 omits his own role entirely. 
First, although Aeschines' character (unlike Demosthenes') may be thought to have no direct connection to the indictment, Demosthenes' strategy throughout his speech has been to assess his public career by comparison with what others, especially Aeschines, did or did not do at the time (e.g., 23, 35-36, 132-34, 136, etc.). Such a comparison is not unreasonable: Aeschines had been his main political rival during the period in question, and it would thus be quite natural to assess Demosthenes' political actions by comparison with the main alternative at the time, namely Aeschines' conduct and policies during the same events. In our legal system, with a (theoretically) disinterested public prosecutor, questions about the prosecutor's character or public career should not arise, but the nature of Athenian procedure meant that one's opponent in court might often also be a political opponent. Second, each of the two main passages of invective in this part of the speech (122-31 and 252-75) leads directly to an attack on Aeschines' conduct during the period in question. In both cases Demosthenes ties Aeschines' lowly upbringing and disreputable early career directly to his later traitorous conduct, presenting Aeschines' life as a consistent development from his servile childhood and youth to his traitorous servility to Philip.

The main issue in the case, Demosthenes' career, is thus assessed by comparison with Aeschines' career, and Aeschines' career, in turn, is illuminated by the discussion of his character, including his family and upbringing. In this way, the memorable passages of vitriol in On the Crown are ultimately, albeit loosely, connected to the issue of Demosthenes' public career: his policies may have failed, but no one at the time, least of all Aeschines, offered a better plan or showed as noble a character. Demosthenes' harsher passages of abuse may still be judged irrelevant; hence he blames Aeschines for starting this line of argument. But his discussion of Aeschines' character is, nonetheless, more closely connected with the main issue of the case than is generally acknowledged.

I hope to have shown by the above analysis that when we understand the concept of relevance in Athenian law in the same precise way as the Athenians did, it becomes clear that both litigants in the case On the Crown are well aware of the issues in the case as specified in the indictment, and that for the most part they address their arguments to the charges specified. They know that the jurors (and others) are also aware of these issues and they take pains to justify themselves whenever they sense that they might appear to be straying outside the issue. Some of these justifications may stretch the concept of relevance, but the mere fact that an argument raises political issues or discusses character does not make it irrelevant. If the argument addresses a point specified in the indictment, then it is relevant under the law. And although the expression to paranomon, "illegality," is used in graphē paranomōn cases to distinguish a certain kind of narrow issue, the broader issues raised in these cases are not fundamentally different with respect to relevance.

This same explicit connection between relevance and the indictment evident in both speeches for the case On the Crown can also be seen in other cases, 
though examination of the full corpus of forensic speeches would require a much larger study. Moreover, as noted earlier, the specific wording of the complaint is preserved in only two other cases for which speeches survive, Demosthenes 37 and 45. A brief look at these, however, shows a similar awareness of the role of the accusation in determining relevance.

Demosthenes 37 (Against Pantaenetus) is a paragraphe case objecting that the suit for damages $($ blabe $\bar{e})$ that Pantaenetus had brought against the speaker, Nicobulus, was inadmissible because Pantaenetus had earlier given Nicobulus a release from all claims. In the course of the speech Nicobulus does not cite his own paragraphe complaint, which presumably asked the court to dismiss the case because Pantaenetus had previously given Nicobulus a release, but he does cite extensive portions of Pantaenetus' complaint (enklèma) in the original case, to which he is objecting (37.22-32). And since this case, like most paragraphē cases, presents not only procedural arguments for the inadmissibility of the original case but also substantive arguments to refute the charge in the original case, in which Nicobulus was the defendant (cf. 37.1), ${ }^{31}$ Pantaenetus' original complaint should, according to the thesis presented above, also control most of Nicobulus' substantive arguments in this case.

And so indeed it does. After a brief prologue (1-3) and a narrative account, supported by witnesses, of the events up to and including the release from claims (4-16), Nicobulus first argues that Pantaenetus' case is inadmissible on procedural grounds (17-20), and then disputes the original charge against him (22-34) by having the clerk read out Pantaenetus' original complaint in pieces (in 22, 25, 26, 27, 28, 29, and 32). After addressing these substantive complaints, Nicobulus returns to the matter of inadmissibility (35-38), argues about a challenge Pantaenetus offered him in the course of bringing the earlier case (39-44), and discusses the very similar case against Euergus, Nicobulus' one-time partner in the venture, which Pantaenetus won, allegedly by lying to the jury (45-51). He concludes by defending himself against attacks on his own personal character, which (he claims) Pantaenetus will make in trying to win his (original) case (52-56), and adds a brief summary (57-60).

As in the speeches On the Crown, the argument about character might be thought irrelevant to the issue (e.g. Rhodes 2004: 150), but like Demosthenes, this speaker too justifies it as a response to what his opponent will say (52), though when he is finished, he adds rhetorically, "But what has all this to do with my dealings with you, Pantaenetus?" In other words, the argument ought to be irrelevant, but since Pantaenetus, the original plaintiff, will introduce it, Nicobulus must respond (so to speak). Whatever the jury made of this justification, it is clear that virtually all of Nicobulus' other arguments are relevant either to the procedural issue of the admissibility of the case or to the substantive issues specified in Pantaenetus' original complaint; where the relevance of an

31. See Wolff 1966, and the brief discussion in MacDowell 2004: 12-13. 
argument is questionable, Nicobulus acknowledges this possibility but also offers a justification. Here too, then, the litigant either sticks to the issues, which are determined by the original complaint, or tries to justify any argument that may appear to be outside these issues.

The other case for which the complaint is preserved, Demosthenes 45 , is a suit for false witness brought by Apollodorus against Stephanus, who had testified against Apollodorus in an earlier trial in which Phormio had sued Apollodorus and won. Stephanus' deposition (which Apollodorus cites at 45.8) had involved the will of Pasion and a challenge to open that document and read it. As in other cases of this type, Apollodorus' complaint is straightforward (45.46): "Stephanus testified against me falsely when he testified to the written contents of the document (to grammateion)." Apollodorus devotes the first half of his speech (9-52) to points directly related to his accusation of false witness and Stephanus' deposition in the earlier trial. The arguments that occupy the last third of the speech, however, are directed more at blackening the characters of Stephanus (53-71) and Phormio (72-85), though some of them touch on matters related to either this case or Phormio's original suit. Apollodorus makes some attempt to justify these arguments in terms of justice, arguing for example that it is all the more just that Stephanus' false testimony be punished because he is a kinsman (53), but he later explains that he will discuss these matters so that the jury will better appreciate Stephanus' villainy, and he himself will feel better (57), and he ends by saying he has introduced these matters so that the jury will know how badly he is being treated by his opponents.

Explanations such as these indicate that Apollodorus is aware that in this case he cannot link his discussion of his opponent's character to the indictment, and that he is therefore speaking outside the issue in the case; but he nonetheless tries to offer some justification for including this material, arguing that the jury should hear about these matters so that they will know that punishment of Stephanus is fully justified. ${ }^{32}$ It seems that when litigants introduce material they think is probably not relevant, they still try to explain why they are doing so in terms that connect the material to the main issue. Thus, most of Apollodorus' argument is directly relevant to the accusation in the case, and when he strays into other matters, he indicates in some way that he is aware that he is doing so. In this respect, the case is not inconsistent with the conclusions reached in the case On the Crown. Even when litigants are not speaking to the issue, they are aware of what the issue is and try in some way to justify their appearing to stray from it. But for the most part they do stick to the issues as defined in the plaintiff's initial accusation.

Now, the control exerted by the initial charge meant that the pleadings in Athenian courts were more tightly regulated than traditionally thought, since the wording of the accusation would provide the framework for these pleadings,

32. Litigants commonly introduce reasons such as this (Lanni 2006: 62-64). 
though it would not determine every argument that could be made. ${ }^{33}$ Thür claims that by linking relevance to the initial accusation, Athenian law promoted fairness in much the same way as the restriction that only documents that had been presented during the preliminary hearing could be cited in court: both rules were intended to "protect the litigants from unforeseeable attacks during the main trial in accordance with the principle of fairness" (Thür 2008: 65-66). However, although Thür's claim may have some truth to it, a far more significant effect of this rule of relevance was that it gave the plaintiff a significant amount of control over the course of the trial. By determining the wording of the accusation, he could to some extent control the course of the arguments on both sides. The plaintiff had other significant advantages as well; not only did he choose whether or not to bring the suit in the first place, he also chose which procedure to use when (as often) more than one was available. And just as he chose the procedure that best suited him, so too he devised the specific wording of the accusation in such a way that he would have the best chance of success.

To be sure, in common law at least plaintiffs and prosecutors today choose whether to prosecute, and in many cases choose what charges to bring; they must also specify the particulars of their complaint. But there are some significant differences. First, today a judge can and often does reject a charge brought by a plaintiff or prosecutor, citing points of law that restrict the use of different procedures. In Athens, officials apparently were reluctant to reject a charge, and when they did so, it seems that they also proposed changes that if made would make the charge acceptable. In three cases (Antiphon 5, Hyperides 1 Lyk., 4 Eux.), the officials in charge allowed the case to proceed despite objections from the defense. In two other cases (Lysias 13, Isaeus 10), the officials in charge would not allow the case to be brought unless the litigant amended his accusation. In the first of these the plaintiff was allowed to proceed after he had added to his accusation the expression ep' autophōrō, "caught in the act" (Lys. 13.86), even though this was patently untrue. In the second case the change may have been more significant: the claimant was required to add to his petition a detail about his mother's relationship to the deceased that may have significantly affected his claim to the estate (Is. 10.2) though it is not clear to what extent if any it weakened it.

Second, Athenian plaintiffs were much less restricted in filing their accusations. Because Athenian laws generally identified only broad categories of behavior like asebeia or hybris without further specification, plaintiffs had to define in their own terms the conduct they were alleging was wrong. Under the rubric of hybris, for example, one could include a wide variety of alleged wrongs, including rape, assault, and several other sorts of mistreatment, as long as one could claim that the act both harmed and dishonored the victim. Multiple wrong-

33. Aeschines' accusation allowed him to include a discussion of Demosthenes' character but did not require him to do so. 
ful acts could also be included together in the same accusation, as we saw, for example, in the indictment of Socrates.

Once the case was brought, defendants did not normally challenge the accusation on the grounds that the wrongdoing alleged was not wrong, though they did sometimes argue that it would have been more appropriate to bring the charge under a different category of offense. ${ }^{34}$ This is in clear contrast to defendants' willingness to challenge the plaintiff's other two initial decisions. Objections to bringing suit in the first place were not uncommon, with defendants often alleging either that the plaintiff had been bribed to bring suit (as in Antiphon 6), or more vaguely that he is acting as a sycophant. Objections to the procedure chosen by the plaintiff occur in the three speeches we noted above (Antiphon 5, Hyperides 1 Lyk., 4 Eux.). Objections to a specific charge, on the other hand, are directed at the validity of the charge, not at the plaintiff's decision to include it in his accusation. ${ }^{35}$

As a partial counter-balance to these prosecutorial advantages, the Athenians enacted laws against frivolous prosecution, which at least in public cases, could put plaintiffs at considerable risk. ${ }^{36}$ Thus, although plaintiffs appear to have had virtually unlimited freedom to devise their accusations, they had to take care to make these as plausible as possible, especially when they might risk severe penalties if they lost or lost decisively. But just as today, Athenian plaintiffs may also have tended to include as many charges as they thought might succeed in the hope of obtaining a conviction on at least some of them. In any case, it is clear that determining the specific details of the accusation must have been one of the more important decisions made by plaintiffs, with far-reaching consequences for the strategies they then adopted in their pleas.

A critic might complain that by giving plaintiffs such free rein to include whatever they wished in their accusation, Athenian law allowed litigants to turn virtually any matter into a legal issue. To some extent this complaint is valid, and although in practice there must have been limits, a very wide range of conduct could be construed as wrongdoing under one of the broad categories of offenses in Athenian law. The range of relevant issues in an Athenian case could thus be much broader than in a modern legal system; at the same time, the Athenian view of law —of what counted, or might count, as legal—was broader than it is today, encompassing not only conduct covered by specific statutes but also, as we have seen, conduct that violated law more generally (or "all the laws"). Scholars have tried to account for this situation in terms that are congenial to modern law. Wolff allowed among the legitimate legal arguments in a graphe paranomōn case those based on general legal principles that could be derived

34. E.g., Ant. 5.9-10, Dem. 37.33.

35. See above, n.24 on Lycurgus' indictment of Leocrates; nothing suggests that Leocrates in fact argued that leaving the city should not have been included in a charge of treason.

36. See Harris 1999 (reprinted in Harris 2006a: 405-22). 
directly from existing statutes. ${ }^{37}$ Lanni (2009) and Sundahl (2009) argue that the legal arguments can include those based on broad democratic principles that can be considered "constitutional," despite significant differences between the Athenian constitution and that of the United States.

A better approach, however, is to accept that the Athenian concept of law was broader than our own. For them, law was not just a matter of written statutes, but could include the broad set of customs or traditional rules that the Athenians generally accepted whether or not they were enshrined in statute. ${ }^{38}$ This is nomos in its broader sense, and even though speakers can use this term with clear reference to written statutes, it always retains at least a hint of this broader sense. This is why the Athenians can honestly emphasize the importance of law and adherence to the rule of law, even when they might appear to us to be straying rather far from anything we would recognize as law. On this view of law, they were indeed adhering to the rule of law.

There is more to be said about the Athenian view of law and the rule of law, but this would take us beyond the scope of this paper, which has focused on the question of relevance. But I hope to have shown how relevance was determined in Athens, and how this concept of relevance allowed such a broad range of issues to be legitimately introduced into litigants' pleadings. It was not that the Athenians simply allowed political arguments of any sort into their legal proceedings, but they allowed such arguments and any others that met their clear standard of relevance, namely arguments that were tied directly to one of the points in the plaintiff's accusation. We do not need to abandon the distinction between legal and political issues, but with respect to the question of relevance in Athenian litigation, the distinction is irrelevant.

University of Texas, Austin gagarin@austin.utexas.edu

37. Wolff 1970: esp. 49-67; such principles can be most easily seen in Demosthenes 23.

38. The law ted by Andocides (1.85), "The magistrates are not to use any unwritten law (agraphos nomos) on any matter whatsoever," would not prevent a litigant from referring to generally accepted customs and values. 


\section{BIBLIOGRAPHY}

Bers, V. 1985. "Dikastic Thorubos.” In P. Cartledge and F. D. Harvey, eds., Crux: Essays Presented to G. E. M. de Ste. Croix on his 75th Birthday, 1-15. Exeter.

Carawan, E. 2007. "The Trial of the Arginousai Generals and the Dawn of Judicial Review." Dike 10: 19-56.

Carey, C. 2000. Aeschines. Austin.

Gagarin, M. and D. Cohen, eds. 2005 The Cambridge Companion to Ancient Greek Law, Cambridge.

$\rightarrow$ Gwatkin, W.E., Jr. 1957. “The Legal Arguments in Aischines' Against Ctesiphon and Demosthenes' On The Crown." Hesperia 26: 129-41.

Hansen, M.H. 1974. The Sovereignty of the People's Court in Athens in the Fourth Century B.C. and the Public Action against Unconstitutional Proposals. Odense.

Harris, E. M. 1994. "Law and Oratory." In I. Worthington, ed., Persuasion: Greek Rhetoric in Action, 130-50. London.

_. 1999. "The Penalty for Frivolous Prosecutions in Athenian Law." Dike 2: $123-42$.

- 2000. "Open Texture in Athenian Law." Dike 3: 27-79.

- 2006a. Democracy and the Rule of Law in Classical Athens: Essays on Law, Society, and Politics. Cambridge.

. 2006b. "The Rule of Law in Athenian Democracy: Reflections on the Judicial Oath.” In M. Faraguna, ed., Nomos Despotes: Law and Legal Procedure in Ancient Greek Society. Ethics and Politics 8: 55-74. Trieste.

Harrison, A. R. W. 1971. The Law of Athens. Vol. 2: Procedure. Oxford.

Lanni, A. M. 2005. "Relevance in Athenian Courts." In Gagarin and Cohen, eds., 112-28. Cambridge.

. 2006. Law and Justice in the Courts of Classical Athens. Cambridge.

- 2009. "Judicial Review and the Athenian "Constitution." In M. H. Hansen, ed., Démocratie athénienne-démocratie moderne: Tradition et Influences, 235-76. Geneva.

MacDowell, D. M., ed. 1971. Aristophanes Wasps. Oxford.

- 2004. Demosthenes 27-38. Austin.

. 2009. Demosthenes the Orator. Oxford.

Mirhady, D. C. 2007. “The Dikasts' Oath and the Question of Fact." In A. H. Sommerstein and J. Fletcher, eds., Horkos: The Oath in Greek Society, 48-59. Exeter.

Rhodes, P. J. 1981. A Commentary on the Aristotelian Athenaion Politeia. Oxford.

- 2004. "Keeping to the Point." In E. M. Harris and L. Rubinstein, eds., The Law and the Courts in Ancient Greece, 137-58. London.

Sundahl, M. J. 2000. The Use of Statutes in the Seven Extant graphe paranomon and graphe nomon me epitedeion theinai Speeches. Diss. Brown University.

ـ 2009. "The Living Constitution of Ancient Athens: A Comparative Perspective on the Originalism Debate." The John Marshall Law Review 42: 463-504.

Thür, G. 2007. "Das Prinzip der Fairness im attischen Prozess: Gedanken zu Echinos und Enklema. In E. Cantarella, ed., Symposion 2005, 131-50. Vienna.

_ 2008. "The Principle of Fairness in Athenian Legal Procedure: Thoughts on the Echinos and Enklema." Trans. of Thür 2007. Dike 11: 51-73. 
Todd, S. C. 1993. The Shape of Athenian Law. Oxford.

. 2005. "Law and Oratory at Athens." In Gagarin and Cohen, eds., 97-111. Cambridge.

Wankel, H. 1976. Demosthenes, Rede für Ktesiphon über den Kranz. Heidelberg.

Wolff, H. J. 1966. Die attische Paragraphē. Weimar.

. 1970. "Normenkontrolle" und Gesetzesbegriff in der attischen Demokratie. Heidelberg.

Yunis, H. 1988. "Law, Politics, and the Graphe Paranomon in Fourth-Century Athens." GRBS 29: 361-82.

. 2005. Demosthenes, Speeches 18 and 19. Austin.

Yunis, H., ed. 2001. Demosthenes, On the Crown. Cambridge. 